Снежана С. БАШЧАРЕВИТ ${ }^{*}$

Универзитет у Косовској Митровици Учитељски факултет у Лепосавићу
Оригинални научни рад

Примљен: 24. 9. 2020.

Прихваћен: 25. 2. 2021.

\title{
ИСТОРИЈСКИ ИМПУЛС У „СЕОБИ СРБАљА” ПЕТРА ПАЈИЋА
}

\begin{abstract}
Дух родољубља код нас је присутан у начину живљења и поимања света. Он није толико транспарентан нити наметљив, али се једнако обнавља и евоцира у уметности, а посебно у књижевности. Мотив историје и родољубља манифестовао се на специфичан начин кроз песнички опус Петра Пајића. Сматрајући да је случај овог песника у контексту српске савремене поезије још увек недовољно расветљен, требало би превредновати његову поезију. Пајићеве родољубиве песме говоре о српском менталитету и погубној историји. Рад има за циљ да укаже на историјски импулс у Пајићевој поезији на примеру песме „Сеоба Србаља”. Песма поседује следеће идејне садржаје: историјске, филозофске и етичке. Стога је истраживање применом аналитичко-синтетичке методе нужно. Извешћемо закључак да је у „Сеоби Србаља” заступљена историјска самосвест и да се порекло наше несреће налази у наслеђу.

Кључне речи: П. Пајић, „Сеоба Србаља”, поезија, историја, родољубље, сеоба, Србија, стварност.
\end{abstract}

Прва Велика сеоба Срба се одиграла под пећким патријархом Арсенијем III Чарнојевићем почетком 1690. године, током Великог бечког рата, који је трајао од 1683. до 1699. године. Аустријска војска је успешно ратовала, ослободила је Угарску, Србију и продрла до Македоније. Приликом проласка кроз српске крајеве, Срби су дизали устанке и прикључивали се аустријској војсци 1689. године. У овоме је пећки патријарх Арсеније III Чарнојевић био изузетно ангажован, па је чак претио и изопштењем из Цркве свакоме ко је био у везама са Турцима. Савезнички заповедник Силвио Пиколомини је 1689. године освојио Приштину, Призрен, Пећ и Скопље, које је спалио. Крајем 1689. године, Пиколомини умире од куге, након чега су Турци вратили снагу и кренули у контраофанзиву против Аустријанаца. Истодобно, Французи су, забринути њеним успесима, Аустрији објавили рат, те она своје најбоље трупе повлачи на западну границу. Почетком 1691.

*snezana.bascarevic@pr.ac.rs 
године аустријска војска се повлачи на леву обалу Дунава и Саве. Плашећи се освете Турака, многи Срби, предвођени Црнојевићем, који су у овом рату војно помагали Аустријанце, кренули су за аустријском војском 1690. године у Велику сеобу ка Угарској. Избеглице су се на путу ка Аустрији заустављале у Београду, чије су улице биле пуне лешева поцрнелих од зиме, које није имао ко да сахрани.

Овај историјски догађај инспирисао је Петра Пајића да напише песму „Сеоба Србаља”. Рад разматра историјске мотиве у овој песми, оцењујући да је овај песник припадао песничком кругу који је сигурно закорачио у српску поезију, користећи мотиве историје и родољубља као везивну нит између прошлости и садашњости. Шта је Србија значила за Петра Пајића? Она је за њега представљала певање и живљење бола, јер је песник рођењем и животом дубоко судбински везан за родно тле. Наша пажња у овом раду биће усмерена ка откривању Пајићевог нацрта за симбиозу српског тла и књижевности. У овој песми до изражаја долази осећање припадности националној заједници, земљи, крају, осећање за историјску правду, за националне идеале и за достојанство човека.

Пајићева поезија испуњена је ненаметљивим, али јасно формулисаним рефлексијама, које, доведене у везу, откривају пажљиво разрађен систем идеја прикладних за разноврсна испитивања (филозофска, психолошка, етичка, естетичка, историјска, социолошка). Естеричари би, узимајући у обзир многе изванредне фрагменте о поезији и песницима, у интервјуима који су вођени са њим, могли да пронађу готово све кључне поставке његове поетике. У интервјуима, које је давао за листове „Политика” и „Вечерње новости" осећајући да мора изразити свој стваралачки немир и саопштити сазнања до којих је дошао трагајући за магичном формулом своје поезије, Петар Пајић је проговорио на искрен начин о етичким и естетичким темама, постављајући, истовремено, неколико основних начела на којима је изградио своје дело и која су од самог почетка била у самом средишту његових стваралачких интересовања. Разговори који су са њим вођени садржали су елементе античких филозофских дијалошких трактата и особине чисте уметничке поезије, у којима два сабеседника, воде наоко неважан, угодан разговор, који, неприметно, решава по једну загонетку и отвара врата ка истинама. Петар Пајић је у овим разговорима свакој мисли и сазнању дао уверљивост и тежину. Познавалац Пајићеве поезије у појединим стиховима може да препозна ставове које је песник изнео у интервјуима. Пајић је у својим поетичким начелима афирмисао непоколебљиву веру у живот поезије, која се упркос свим недаћама и тегобама песничког битисања јавља као основна, битна карактеристика културе. На ову тему у интервјуу датом за дневни лист „Политика” изјавио је: „Уметничко дело је духовна творевина и оно једино може бити бесмртно" (Радисављевић 2010: 10). У различитим стваралачким фазама он је поетичке ставове износио на експлицитан начин путем поетичких исказа, а на имлицитни путем поетичких фигура. Ова два начина исказивања поетичких ставова у књижевном делу заједно чине аутопоетику једног писца 
(Перишић 2005: 615). Ради боље илустарције наводимо његов поетички исказ о родољубивој поезији:

„Највећи српски песници писали су родољубиве стихове. Међу њима, истичу се жене: Јефимија, Милица, Десанка. У временима страдања и жртвовања српског народа певало се о томе. Не мислим да су године у којима живимо лакше и боље, али, званично, родољубље се сасвим другачије схвата. Јефимију, Милицу и Десанку, замениле су 'жене у црном'; да је Ђура Јакшић жив, због стихова у којима позива 'Падајте браћо' и 'Бацајте сами у огањ децу', или због оних које је написао о 'тиранки Европи - био би сигурно у Хагу. Његош је већ, као што знамо, проглашаван за геноцидног песника, а песникња 'Крваве бајке за опасну националисткињу. Песнике родољубивих стихова прати променљива судбина: од слављења до хапшења.

Сада, у времену глобализма, код нас није у званичној моди родољубива поезија. Модерно је да се буде против себе. Родољубље је, за многе, фолклор и сметња да се буде Европејац" (Хамовић 2011: 213).

У разговору са Десанком Максимовић, вођеном 1984. године, а чију је награду понео 2014. године, Пајић бележи одговор своје земљакиње на питање откуд потиче родољубиви импулс у њеној поезији: „Родољубиво осећање рађа се из осећања великог националног пораза. Тај стид од пораза за који ниси крив, тај велики бол који су сви осећали, пробудио је у мени родољубива осећања" (Пајић 2007: 44).

Ове Десанкине речи можемо сматрати и једним од начела Пајићеве поетике. Награду је добио, јер обоје имају идентичну песничку стазу која је, пре свега, родољубива, национално обојена. То је српска стаза.

Његова поезија своје садржине крије дубоко у себи, испод смирене, уздржане и отмене спољне једноставности. Знајући да и најдубљу филозофску мисао можемо изразити песнички, Пајић је истовремено и филозоф и песник, који на превасходно уметнички начин излаже начела своје поетике, у којој се налази одговор на свако питање што га поставља, одгонетка за све што се у њој скрива и прави кључ за њено разумевање, јер смисао поезије није у томе да сопственим, оригиналним сликама и фигурама копира свет и постојање, него је њен смисао у томе да проникне у изворни смисао света и постојања (Фридрих 2003: 69).

У средишту Пајићевог родољубивог песничког израза јесте присна слика кроз време намучене отаџбине. Он је 2009. године добио награду „Одзиви Филипу Вишњићу”, коју додељује Задужбинарско друштво „Први устанак” за родољубиву поезију, односно за транспарентни израз ововременог родољубља, а 2010. године „Жичку хрисовуљу” за дубински песнички портрет Србије предачке и савремене. Пајић је песник чије су песме ушле у народ и једнако је препознатљив како својим именом, тако и насловима својих песама, односно, наслови његових песама постали су његово друго име. 
Тему избеглиштва он је најавио кроз лирску тематизацију прве строфе песме „Сеоба Србаља”:

„Гори месечев рог испод чела.

Пада црна киша дуж пута.

По Угарској серпско племе лута,

За Чарнојевићем, лица невесела" (Пајић 2004: 82).

У застрашујућем виђењу пејзажа огледа се сав удес народа којем припада. Арсеније Чарнојевић постаје оличење отаџбине. Недоумица између пораза и празника даје овој строфи кључну семантичку двосмерност. Народ лута просторима над којим се надносе тамни, тешки облаци и стално га засипа црна киша. Стално присуство симбола који упућују на воду, кишу и блато имају скривено значење. На општем плану, овакви простори егзистенције, доминација водене стихије и њених пратилаца, указује на немогућност живљења, на загушен живот.

У следећој строфи Петар Пајић се исказао као стваралац потпуне отворености према животу и стварности. Он је велику трагедију и национални погром транспоновао у књижевно дело у време велике етичке депресије и расапа, с једне стране и етничке угрожености сопственог народа, с друге стране:

„Лето. Падају из ваздуха запаљене птице.

Остадоше по путу мртве краве.

Пожар сунца разбија нам главе.

Син очево не познаје лице" (Пајић 2004: 83).

Када је реч о стваралачком поступку и односу према стварности, он не избегава тешке садржаје живота. Његова поезија је и молитва и клетва. Уме да буде меланхолична и до бола реалистична, готово документарна, што је чини тематски сложеном и идејно асоцијативном.

Историјска појава колективних сеоба подстакла је писца да се запита где су клице порива за покретом, вечитим лутањем и трагањем:

„Смрди овнујска кожа преко леђа.

Мокри црна киша по непознатом крају.

Старци се у пољима клечећи моле и кају

Носећи завичајна брда између веђа" (Пајић 2004: 82).

У овој строфи емотивно и рефлексивно је потиснуло догађај који је само импулс за унтрашња преживљавања, душевне дилеме и недоумице, мисаоне преокупације и рефлексивне узлете обојене чежњом и надом. У ову строфу ушла је врло богата тематика историјског, егзистенцијалног, психолошког, моралног и филозофског порекла.

Петар Пајић дубоко је преживљавао историјске ломове и својом имагинацијом претварао их у чисту поезију. Отуда су у његовом делу остварене моћне синтезе историје и поезије. Све његове песме за подстицај имају дубинске историјске потресе. Рат и огромни покрети маса подстакли су га да се окрене управо таквим догађајима: 
„Закаснило је наше племе на путу.

За наше главе долазе убице.

Топећи сребро дуж широке равнице

Разбојнички осећамо месечину жуту" (Пајић 2004: 83).

Пајић је у експлицитним исказима често истицао да сви догађаји, ма како они били потресни и значајни, временом одлазе у заборав. По његовом мишљењу, историјске чињенице постајући уметничке, отржу се забораву и трајно живе у свести читалаца уметничког дела.

Тематски посматрано он је покушао да у својим песмама представи подручје Србије и живот у њој. Оно што му је било најбитније јесте да песме буду прихватљиве за све који ту живе. Повезујући Пајићеву експлицитну и имплицитну поетику можемо закључити да је сударање литературе и живота у његовом стваралаштву очигледно присутно. Већ смо указали да је присуство историјских мотива битна компонента поезије овог песника. Овде превасходно имамо у виду тему која је подједнако историјска и савремена, уметничку баштину која чини темеље српског духовног и националног идентитета. А, ништа теже него носити свој идентитет, написао је у својим записима Иво Андрић. Да би изразио све то, Петар Пајић је морао да има велико поверење у песничку реч, у њену моћ, и да новом „читању” историје и традиције приђе на аутентичан начин, не понављајући моделе традиционалних песничких поетика:

„Осуђени на пораз, Сербљи, болно.

Издајица је ту и већ план кује.

Кроз тело, као преко бојишта, меци зује.

Долази вече, а битке нема. Оловно" (Пајић 2004: 84).

У следећим стиховима представљена је Србија на граници:

„Издајица је већ ту. Издајица је већ ту.

Близу смо Севера, али не можемо стићи.

Нити се можемо вратити. Даље ићи, ићи, ићи.

Поред угашених ватри на путу" (Пајић 2004: 84).

Песник сматра да су сеобе сталне у судбини српског народа. Њихов узрок је у притиску војне силе или зулума, али и у трагању за обећаном земљом која ће пружити уточиште, спокој и смирење.

Пајићева поетика поезију види и као сведочанство, а песника као сведока. То је још једна суштинска одредница књижевног стваралаштва овог песника. Његово сведочење о прошлости и садашњости у својеврсном су паралелизму, сложеном међусобном односу и преплитању:

„Са секирама заривеним у слепоочнице

Путује се на Север. На Северу нема наде.

Добар је ко убија и ко краде.

Према срцу окренуте су оштрице” (Пајић 2004: 84). 
Када је ушао у проблем сеоба, песник је схватио колико је он сложен као историјска појава, колико је утицао на судбину српског народа и колико је овај народ губио у тим сеобама и страдао због изневерених очекивања.

Ниједна уметност не бави се толико феноменом времена као књижевност, посебно поезија: било да трага за оним што је изгубљено или за оним што је актуелно (Ћулавкова 2001: 105). Сећање на прошлост преображава се у пев о садашњости. Пајићева Србија, у овој песми је противречна. Дата је кроз слику тамног оргијастичког пијанства и реалности:

„Плаче дете у мајчином трбуху.

Зло се коти у чистом цвету.

Алкохол сунца улази у крв цвету.

Јаук се разлеже и одјекује по слуху” (Пајић 2004: 83).

Поводом поезије Петра Пајића увек се говори о искрености, што је синоним за аутентичност и лирски таленат:

„Бакарне ватре остају по страни.

Кочеви ничу из поспалих глава.

Ветар се извлачи из модрог Дунава.

Ко вране, позади, пролетеше дани" (Пајић 2004: 82).

У овој строфи је сумирано негативно животно искуство, које је узроковало негативна осећања и негативан став према животу. То искуство казује да на крају дође дан када човек посустане у непрестаној борби и трагању за резултатом живљења и његовим смислом. Тренутак тог сазнања је крај животног пута на коме нема никаквих резултата, када се гаси животни жар и човека обузме разарајућа равнодушност. У таквом душевном стању сумња руши и веру и наду. Ова строфа је израз апсолутног безнађа. Одбацују се као узалудне све тежње и наде, мири се са стањем у коме се нашла јединка и задовољава ситним мрвицама живота. Ход кроз живот је бесмислен, јер је он само кошмар, освојени идеали нису оно право чему се тежило. Бесперспективност и мрачни песимизам избијају из ових стихова.

Лирски субјект у његовим песмама носи велику унутрашњу драму, било да је заточеник у свету или је сасвим ослобођен животних норми и оквира. Људи јесу ковачи споствене среће и несреће, али о многим стварима, често и оним суштинским, одлучују други, затим околности, непредвидљиве случајности, више но што то на први поглед изгледа. Српска драма је у средишту читавог књижевног стваралаштва и ангажмана Петра Пајића. Она му је дала суштинска својства и идентитет. Песме су му и документована стварност о страдању, избеглиштву и изгубљеном завичају. Када је хиљаде и хиљаде невољника прокаженог народа прогнано, Пајић је одговорио не као бучни трибун, него као сабрат што има очи да види и прозире у дубину догађаја. Његова родољубива поезија везана је за биће српског народа, за све што чини традицију и баштину, за прогонство као усуд.

Питање родољубиве поезије је и питање опстанка српског народа и бол за српском земљом. Код Пајића Србија избија као митопоетска тема. Српски 
бол тражио је песника који ће у крвотоку своје поезије носити архетип античке трагедије, а у срцу своје песме отаџбински завет. Он је у својим песма приказао драму српског страдања, овоземаљски и космички бол виђеног и неслућеног, где се реално ближи иреалном и обрнуто, али и кондензовану човекову зебњу пред српским и свеопштим удесом. То је поезија која у најширем смислу значи ламент над Србијом и јавља се као надмоћ у односу на ужас, уверавајући нас да је песник дорастао једном тако великом животном и литерарном чину. Метафизичка стрепња и студ не затвара ову поезију, како би је заробила и обеснажила, већ враћа живот том народу, уливајући му наду и стоицизам.

Родољубива поезија Петра Пајића представља вертикалу српског страдања, али и трајања и отпора, којом је песник подигао вечни споменик српским страдалницима и српској земљи. На нашем тлу, не страда само човек, Србин, него и његова културна и материјална добра, зато су многе песме духовног садржаја, у чијем је средишту богата слојевитост, поетска отменост и суптилан израз. Петар Пајић је песник са јасним ставом према историјским и актуелним догађајима. Огледало националне историје - огледало је песникове душе. Са јаким и јасно исказаним патриотским осећањима поклоничке љубави и дивљења према духовном наслеђу и историјском предању о осведоченом јунаштву и херојској истрајности предака, у својим песмама он је исписао странице које, почивајући на трагичном, али светом историјском искуству, исијавају безрезервном вером у ренесансну будућност и у њима је човек, тако типични пајићевски лирски јунак, онај који тежину патњи и величину и славу победа износи на својим плећима.

Узев у целини, српска родољубива поезија је дубоко прожета и условљена националном историјом, тако да се једним својим делом природно прелива у правцу критичког односа. У томе погледу је нарочито драгоцено песништво Петра Пајића, које се преображава у стишану патриотску оданост и понос над дивним пределима српства, али и у меланхоличну сумњу да је можда славна прошлост неповратно минула. Песник пева из најличније позиције о националном удесу српског народа, тј. о његовој унесрећености. Он опева српску удесну драму (и појединачну и колективну), теготу и мучнину живљења на рођеној земљи. Родољубива поезија Петра Пајића је испевана пунокрвно, звонко и јасно. Блистава енергија исијава из њеног тона, из чистог лирског гласа који буди неумрла сећања и крепи душу благошћу и вером у постојаност победа: радних, ратних, духовних. Вера у национални опстанак и ренесансу расте из песникове свести о трагичној историјској судбини народа из чијег духа се издигла и чијој благодатнијој будућности стреми.

На крају закључујемо да је Петар Пајић свој песнички флуид, своју лирику и лични доживљај претворио у велику слику, у општу појаву и широко кретање, али да ово певање има и другу релацију: то је унутрашње усмерење где је он опште претворио у лирско. То је његова двосмерна молитва за српски усуд. Пајић је трагедију српског поднебља пратио мотивима историје, родољубља и завичајном интонацијом, као најприкладнијим метафоријским смислом. Његову родољубиву поезију можемо окарактерисати као дневник 
дубоког и личног доживљаја који се односи на све Србе. Пајић исказује суштинско незадовољство лирског субјекта спољашњим светом, као и отпор према отуђеној стварности и профанисаном друштвеном животу. Једну од најбитнијих, а вероватно најзначајнијих линија његове поезије чине песме о Србији, њеној традицији, култури и менталитету. У његовим родољубиво-историјским и меланхоличним песмама проговорила су различита лица и времена Србије, у широком распону од породичних до националних. Песник не скрива свој став да нисмо способни да учимо из онога што нам се дешавало, па зато никаква озбиљна порука нема сврху. Петар Пајић је певао и промислио историјски удес српског народа. Он је у Србији видео стравичне призоре библијских димензија, митске слике препуне неспокоја, владарске обрачуне, разједињеност и неслогу српског народа, братоубилаштво, ратна разарања и погибије невиних. Петар Пајић је српску стварност претворио у метафору, у симбол, у стих и својом поезијом обележио савремену српску стварност, а печат јој је дао историјски импулс.

\section{ЛИТЕРАТУРА}

Бахтин 1991: М. Бахтин, Аутор и јунак у естетској активности, Нови Сад: Светови.

Деретић 1997: Ј. Деретић, Поетика српске књижевности, Београд: Филип Вишњић.

Ђорђевић 2013: Б. Ђорђевић, Где су биле кафане сада царују банке, Вечерње новости, 05. 10. 2013, 7.

Ђурић 1965: В. Ђурић, Лирика, Београд: Завод за уџбенике и наставна средства.

Еко 1965: У. Еко, Отворено дјело, Сарајево: Веселин Маслеша.

Еко 1995: У. Еко, Симбол, Београд: Народна књига.

Јовичић 1973: В. Јовичић, О родољубивом лирском надахнућу, Београд: Книжевна историја, 19, Београд, 63-75.

Лотман 1976: Ј. Лотман, Структура уметничког текста, Београд: Нолит.

Пајић 2004: П. Пајић, Најлепше песме Петра Пајића, Београд: Просвета.

Пајић 2007: П. Пајић, Нешто као, Бања Лука: Арт принт.

Пајић 2015: П. Пајић, Поезија, Београд: Задужбина „Десанка Максимовић”, Народна библиотека Србије.

Палавестра 1995: П. Палавестра, Историја модерне српске књижевности. Златно доба 1892-1918, Београд: СКЗ.

Перишић 2005: И. Перишић, Прилог за дефиницију термина аутопоетика, Београд: Кьижевна историја, 127, Београд, 615-626.

Радисављевић 2010: 3. Радисављевић, Поезији није одзвонило, Политика, 19. 08. 2010, 10 .

Саболчи 1997: М. Саболчи, Авангарда и неоавангарда, Београд: Народна књига. 
Скерлић 1908: Ј. Скерлић, Обнова наше родољубиве поезије, Београд: Српски кьижевни гласник, 6, Београд, 38-46.

Солар 1971: М. Солар, Питања поетике, Загреб: Школска књига.

Станишић 2016: М. Станишић (ур.), Поезија Петра Пајића: зборник радова, Београд: Задужбина „Десанка Максимовић”, Народна библиотека Србије.

Станковић 2005: Д. Станковић, Књиге у сенци, Вечерње новости, 03. 12. $2005,9$.

Ћулавкова 2001: К. Ћулавкова, Поетика лирике, Београд: Народна књига, Алфа.

Фридрих 2003: Х. Фридрих, Структура модерне лирике: од средине 19. до средине 20. века, Нови Сад: Светови.

Хамовић 2011: Д. Хамовић (ур.), Петар Пајић песник, Краљево: Народна библиотека „Стефан Првовенчани”.

Човић 1989: Б. Човић, Поетска слика, Нови Сад: ИСКЈ.

Шутић 1987: М. Шутић, Лирско и етика, Београд: Институт за књижевност и уметност.

Snežana S. Baščarević

HISTORICAL IMPULSE IN „MIGRATION OF SERBS” BY PETAR PAJIĆ

Summary

The spirit of patriotism is present in our way of living and understanding the world. It is not so transparent or intrusive, but it is equally renewed and evoked in art, and especially in literature. The motif of history and patriotism manifested itself in a specific way through the poetic opus of Petar Pajić. Considering that the case of this poet in the context of Serbian contemporary poetry is still insufficiently clarified, we re-evaluated his poetry. Pajić's patriotic songs speak of the Serbian mentality and a disastrous history. The aim of the paper was to point out the historical impulse in Pajić's poetry on the example of the song „, Migration of Serbs”. The poem has the following ideological contents: historical, philosophical and ethical. Therefore, research using the analytical-synthetic method was necessary. We have concluded that historical migration is represented in „Migration of Serbs” and that the origin of our misfortune is in the heritage. 